\title{
New industrial city as an element of regional competitiveness
}

\author{
Yelena Borisovna Dvoryadkina \\ Ural State University of Economics, \\ Institute of Economics \\ Yekaterinburg, Russia \\ elena.dvoryadkina@yandex.ru
}

\author{
Yekaterina Igorevna Kaibicheva \\ Ural State University of Economics, \\ Institute of Economics \\ Yekaterinburg, Russia \\ Catherine.kai@mail.ru
}

\author{
Ivan Aleksandrovich Antipin \\ Ural State University of Economics, \\ Institute of Economics \\ Yekaterinburg, Russia \\ aia87@mail.ru
}

\begin{abstract}
The article substantiates a theoretical approach to studying the new industrial cities. It presents the methodology for their selection based on the use of data on the level of development of the city's industry, its contribution to the regionwide performance indicators, as well as the nature of industrial products being manufactured. A hypothesis that regional competitiveness depends on the presence of new industrial cities in the region is put forward and proven.
\end{abstract}

Keywords - new industrial city, city, region, regional competitiveness

\section{INTRODUCTION}

Economic recession and worsening financial situation in most developed countries have again brought the issue of new industrialization to the agenda. The revival of industry based on new technologies is now seen as one of essential preconditions for the future development of territories. After scaling the industrial sector down for many years by shifting facilities outside their borders, the leading powers have again realized the need to bring them back as large employers, taxpayers, and drivers of their national economies.

Competitiveness of a country and its regions today is largely determined by its success in implementing new industrialization. The latter, in turn, has a well-defined territorial binding. As a rule, this refers to the location of industrial facilities. However, if we approach the issue in more detail, it can be said that the space used to implement new industrialization is the cities that have historically been clustering industrial production in their territory. Therefore, we believe it possible to hypothesize that the regions where new industrial cities are present have a distinctly higher level of competitiveness.
The purpose of the article is to verify the suggested hypothesis.

For this purpose, this article deals with the tasks associated with theoretical justification of a concept of "new industrial city", studying the elements of regional competitiveness, and assessing the contribution of new industrial cities to the competitiveness of the respective regions.

\section{MATERIALS AND METHODS (MODEL)}

Theories of new industrial society (J.K. Galbraith), theories of industrial society (R. Darendorf, R. Aron), and theories of post-industrial and information society (D. Bell, A. Touraine, A. Toffler et al) served as theoretical framework for the study. Using the provisions of the above theories, it was possible to develop an author's interpretation of the concept of "new industrial city" and to highlight its essential features.

To identify new industrial cities in Russia, we used statistical information formed by Rosstat and the data from various ratings. For the purposes of this article, we believe it possible to discuss the study of large and largest cities of the Russian Federation in more detail. First, the cities of this rank are usually the leading economic centers. Second, the emergence and rise of some of them (Yekaterinburg, Perm, Chelyabinsk, etc.) is connected to industrial production and/or Soviet industrialization.

Schematically, the process of identifying new industrial cities in the context of modern Russia or another country in the world can be represented as follows.

Step 1. To determine the economic specialization of a city. The simplest way would be to analyze the structure of gross urban product (hereinafter - GUP), equivalent to GDP at the city level. However, in practice, such indicator is not available 
from official statistics, although a number of scientists have attempted to calculate it (e.g. see [1]). Therefore, we believe it possible to determine the economic specialization of a city by calculating the specialization ratio. To do this, we use the following formula:

$$
C_{i r}=a_{i r} / a_{r}
$$

where $C_{i r}$ is the specialization ratio; $a_{i r}$ is the proportion of the number of city employees $r$ in a region by type of economic activity $i ; a_{r}$ is the proportion of the number of city employees $r$ in a region for all types of economic activity.

For the purpose of calculation, we used the average annual number of employees in organizations (for the cities being the centers of the respective municipal entities) and the average annual number of employees (for the federal subjects of the Russian Federation).

Step 2. To assess the degree of the city's industrial development by calculating the relative industrialization level (industrialization index) [2. P.26]. It is calculated by the formula:

$$
I_{i}=\frac{P_{i}}{P}: \frac{N_{i}}{N}
$$

where $P_{i}$ is the volume of home-produced goods shipped, works performed, and services rendered without subcontracting, by types of economic activity such as "Mining", "Processing industries", "Production and distribution of electricity, gas, and water" in city $i ; P$ is the volume of home-produced goods shipped, works performed, and services rendered without subcontracting, by types of economic activity such as "Mining", "Processing industries", "Production and distribution of electricity, gas, and water" in a federal subject of the Russian Federation; $N_{i}$ is the resident population of the city $i$; $N$ is the resident population in the federal subject of the Russian Federation.

The obtained values are interpreted in the following way. If $I_{i} \geq 1$, the city is industrially developed, if less than 1 , the city is not industrially developed.

Step 3. To assess the relevance of the city and its enterprises for the development of regional industrial complex. For this purpose, the proportion of the volume of home-produced goods shipped, works performed, and services rendered without subcontracting by types of economic activity such as "Mining", "Processing industries", "Production and distribution of electricity, gas, and water" of the city in the region-wide performance indicators was used. The main source of information was the data from the statistical book "Regions of Russia. Main socio-economic indicators of the cities" for 2016.

Step 4. To determine the level of technological development of the industry. For this purpose, we used the RBC Rating data for "50 largest technology companies in Russia" [3], the National rating of Russian high-growth technology companies [4], and descriptions of products posted by manufacturers on their official websites and published in open sources.

Step 5. To summarize the obtained estimates. To draw a list of new industrial cities. As new industrial cities were identified those cities that a) have a poly-industrial structure of economy with industrial production still playing the leading role; b) make a significant contribution to the development of the regional industrial complex; c) feature the facilities manufacturing high-tech products.

In this study, we examined 73 cities with a population exceeding 250,000 people. This excludes Moscow and St. Petersburg due to their status of a federal subject of the Russian Federation.

To assess the regional competitiveness, we used the data from publicly available rating by AV Group consulting company, "Index of regional competitiveness - the poles of Russia's growth" [5].

The data from the Federal State Statistics Service represented the informational framework of the study. Due to the fact that Rosstat has started to form statistics broken down by municipalities, all data are given for cities with surrounding areas belonging to one municipal entity.

The time horizon for the study is 2015. This can be explained by two reasons. First, the availability of statistical key figures. Second, the last rating provided by AV Group consulting group is for 2015.

To test the suggested hypothesis, we analyzed the available competitiveness ratings of Russian regions in conjunction with development of new industrial cities in the territory of the respective federal subjects of the Russian Federation.

\section{RESULTS AND DISCUSSION}

\section{A. "New industrial city": definition and characteristic.}

New industrial city as an emerging type of cities has not yet been thoroughly studied in scientific literature. The attention of researchers is mostly focused on the studies into global, world, single-industry, and other types of cities that have already become traditional. From the above, one can conclude that there is a need for a detailed theoretical study of the concept of "new industrial city" and its justification in the areas of regional science and urban studies.

To this end, we believe it possible to use the provisions of industrial and post-industrial concepts in conjunction with key results of modern research addressing various aspects of new industrialization.

When interpreting the essence of the concept of "new industrial city", we deem it possible to proceed from the following basic provisions.

First, industry is one of the most important city-forming forces. As E.G. Animitsa, N.Yu. Vlasova point out, "Only handicraft and later industry were able, first, to gather a considerable mass of workers in one place; second, to feed them on their own; third, to make urban growth almost unlimited..." [6, P. 91]. Not by accident, a socio-economic 
concept of cities comprises their functional typology, where an industrial city is indicated as a separate item.

Second, the urban development processes are determined by the changes that occur in the society. Under the civilizational approach, pre-industrial (agrarian), industrial, and post-industrial societies are identified from the perspective of the theory of post-industrial society. Cities that are typical for industrial society will substantially vary from postindustrial ones (Table 1).

TABLE I. DIFFERENCE BETWEEN THE CITIES IN PRE-INDUSTRIAL, INDUSTRIAL, AND POST-INDUSTRIAL SOCIETY [7, P. 25]

\begin{tabular}{|l|l|l|l|}
\hline $\begin{array}{c}\text { Key features of } \\
\text { urban } \\
\text { development } \\
\text { stages }\end{array}$ & \multicolumn{1}{|c|}{$\begin{array}{c}\text { Pre- } \\
\text { industrial }\end{array}$} & Industrial & \multicolumn{1}{c|}{$\begin{array}{c}\text { Post- } \\
\text { industrial }\end{array}$} \\
\hline $\begin{array}{l}\text { Type of } \\
\text { interaction }\end{array}$ & $\begin{array}{l}\text { Society } \\
\text { interacts with } \\
\text { nature }\end{array}$ & $\begin{array}{l}\text { Interaction } \\
\text { with } \\
\text { modified } \\
\text { environment }\end{array}$ & $\begin{array}{l}\text { Human } \\
\text { interaction }\end{array}$ \\
\hline Technology & $\begin{array}{l}\text { Labour- } \\
\text { intensive }\end{array}$ & $\begin{array}{l}\text { Capital- } \\
\text { intensive }\end{array}$ & $\begin{array}{l}\text { Knowledge- } \\
\text { intensive }\end{array}$ \\
\hline $\begin{array}{l}\text { Type of industrial } \\
\text { activity }\end{array}$ & Extraction & $\begin{array}{l}\text { Manufacturin } \\
\text { g }\end{array}$ & Processing \\
\hline $\begin{array}{l}\text { Major production } \\
\text { resource }\end{array}$ & $\begin{array}{l}\text { Raw } \\
\text { materials }\end{array}$ & Energy & Information \\
\hline $\begin{array}{l}\text { Prevailing sector } \\
\text { of economy }\end{array}$ & Primary & Secondary & $\begin{array}{l}\text { Tertiary and } \\
\text { quaternary }\end{array}$ \\
\hline
\end{tabular}

In this case, one can say that new industrial city is the one whose characteristics and traits are shaped by new industrial society. The latter was described in detail by J.K. Galbraith [8] in his work of the same name. Of the features inherent in the new industrial society he specified the following:

- power removed from owners to the technostructure (i.e. transition from individual to collective decision making);

- large corporations dominate the economy and merge with the state apparatus. This is due to increasing complexity of technological processes and the need for strategic business planning of the corporation;

- active role of the state in the economy associated with the need to develop science and technology.

Third, any city exists in interrelation and interconnection with external environment (economy, politics, culture, etc.). In the minds of scientists (S.D. Bodrunov, S.Yu. Glazyev [9], V.M. Kulkov [10], etc.), strategic perspective of the development of Russia and its regions is currently associated with implementation of new industrialization. The latter involves a combination of three processes, namely reindustrialization, neo-industrialization, and superindustrialization.

Taking into account all the above, let us formulate the author's interpretation of the concept of "new industrial city". A special functional type of a post-industrial city, whose economy is based on a combination of various types of economic activity with industrial production (including the fifth and sixth waves of innovation) being preserved and developed, is its key element.

New industrial city does not emerge out of nowhere. It is a kind of a successor to the industrial city. While the latter is typically dominated by strictly industrial production, new industrial city has a poly-industrial structure with the role of industry being preserved.

In this study, we examined 73 cities with a population exceeding 250,000 people. This excludes Moscow and St. Petersburg due to their status of a federal subject of the Russian Federation.

The list of cities that could be regarded as new industrial ones as of 2015 is presented in Table 2.

TABLE II. N NEW INDUSTRIAL CITIES OF RUSSIA, 2015.

\begin{tabular}{|c|c|c|}
\hline & Federal subject of RF & City \\
\hline 1 & Bryansk region & Bryansk \\
\hline 2 & Voronezh region & Voronezh \\
\hline 3 & Kaluga region & Kaluga \\
\hline 4 & Ryazan region & Ryazan \\
\hline 5 & Tver region & Tver \\
\hline 6 & Kaliningrad region & Kaliningrad \\
\hline 7 & Rostov region & Rostov-on-Don \\
\hline 8 & Republic of Bashkortostan & Ufa \\
\hline 9 & Republic of Tatarstan & Kazan \\
\hline 10 & Udmurt Republic & Izhevsk \\
\hline 11 & Perm Territory & Perm \\
\hline 12 & Saratov region & Saratov \\
\hline 13 & Ulyanovsk region & Ulyanovsk \\
\hline 14 & \multirow{2}{*}{ Sverdlovsk region } & Yekaterinburg \\
\hline 15 & & Nizhny Tagil \\
\hline 16 & Republic of Buryatia & Ulan-Ude \\
\hline 17 & Altai Territory & Barnaul \\
\hline 18 & Krasnoyarsk Territory & Krasnoyarsk \\
\hline 19 & Novosibirsk region & Novosibirsk \\
\hline 20 & Tomsk Region & Tomsk \\
\hline
\end{tabular}

\section{B. Regional competitiveness and its components}

Despite a massive layer of scientific studies on the problems of regional competitiveness, some scientists come to conclusion that "so far, there is no generally accepted theory of regional competitiveness and competitive advantages" [11].

By competitiveness in this case we mean the ability of regional economy to "consistently produce and consume goods and services in competition with the goods and services produced in other regions, while respecting environmental standards and maintaining living standards of the population" [12, P. 278].

For the purpose of our study, we used the ratings of the AV Group consulting company for 2015. We divided all federal subjects of the Russian Federation into two groups. The first group included those incorporating the new industrial cities that we have identified (19 federal subjects of the Russian Federation in total). The second group included the federal subjects of the Russian Federation (except Moscow, 
St. Petersburg, and Moscow and Leningrad regions) with no such cities. Then the average value of competitiveness index was calculated for each group. For regions with new industrial cities, the index value for 2015 was 2.21 . For the second group, it was 1.41. Thus, it can be concluded that new industrial cities can be considered as a component of regional competitiveness.

The hypothesis of our study can be considered proved both theoretically (see theoretical justification for the concept of the "new industrial city") and empirically.

The results of our study are largely controversial. Primarily, the interpretation of the concept of "new industrial city" and the given list may be debatable. However, we think it necessary to make it clear that the authors have no claim to their "absoluteness". In particular, the list may vary depending on what criteria the researchers will use. Designation of some cities as new industrial ones may raise questions. However, in disputable cases, one should remember that the statistics for municipalities, the centers of which are the cities in question, is not perfect. In this regard, we cannot, in particular, take into account the performance of small industrial enterprises. Therefore, in disputable cases, any doubts were solved "in favor" of a city.

For a more competent assessment of new industrial city as a component of regional competitiveness, one may build a regression model with one dummy variable, i.e. the presence/ absence of a new industrial city in the corresponding federal subject of the Russian Federation.

In simple terms, the model can be represented as follows:

$$
\mathrm{Y}=\beta_{0}+\gamma \mathrm{P}+\varepsilon
$$

Coefficient $\beta_{0}$ determines the initial level of regional competitiveness without new industrial city in the region. Coefficient $\gamma$ specifies to what extent the regional competitiveness differs depending on the presence or absence of new industrial city in a region.

\section{CONCLUSION}

In the course of the study, the authors substantiated a theoretical approach to studying the essence of the concept of a "new industrial city" and suggested its interpretation as a special functional type of a post-industrial city whose economy is based on a combination of various types of economic activity with industrial production (including the fifth and sixth waves of innovation) being preserved and developed as its key element.

The proposed hypothesis, the essence of which is that the regions incorporating new industrial cities feature a higher level of competitiveness, is proved both theoretically and empirically.

\section{Acknowledgment}

The article is prepared with financial support from the Russian Foundation for Basic Research under research project No. 18-010-00789A "Development of methodological tools for the study into the economy of a new industrial city in the context of transforming spatial organization of economic activity."

\section{References}

[1] N. Kosareva, T. Polidi, "Assessment of gross urban product in Russian cities and its contribution to Russia's GDP in 2000-2015," Voprosy Ekonomiki [Economic issues ], No. 7, pp. 5-23, 2017.

[2] I.A. Rodionova, Macrogeography of global industry. Moscow: The Moscow Lyceum, 2000.

[3] 50 largest technology companies in Russia: RBC rating, unpublished.

[4] National rating of high-growth technology companies: TechUspech, unpublished.

[5] Index of regional competitiveness - the poles of Russia's growth? AV Group, unpublished.

[6] Ye.G. Animitsa, N.Yu. Vlasov, Urban studies. Yekaterinburg, Published by USUE, 2010.

[7] N.Yu. Vlasova, Structural modernization of the economy of the largest Russian cities. Yekaterinburg: Published by USUE, 2000.

[8] D. Galbraith, New Industrial Society. M., 2004.

[9] S.D. Bodrunov, R.S. Grinberg, D.E. Sorokin, "Re-industrialization of the Russian Economy: Imperatives, Potential, Risks," Ekonomicheskoe vozrozhdenie Rossii [Economic Revival of Russia], No. 1 (35), pp. 1949, 2013.

[10] V.M. Kulkov, "New industrialization in the context of Russia's economic development," Ekonomika. Nalogi. Pravo [Economy. Taxes. Law], No. 2, P. 82-83, 2015.

[11] A.V. Voloshin, Yu.L. Aleksandrov, S.N. Shestov, Ye.V. Belonogova, "Regional competitiveness as a subject of research in economics," Fundamentalnye issledovaniya [Fundamental research]. No. 10-1. Pp. 113-118. 2016.

[12] V.V. Pechatkin, V.A. Perfilov, "Theoretical and methodological aspects of assessing the competitiveness of Russia's regions," Problemy sovremennoi ekonomiki [Problems of Modern Economy], No. 12, pp. 285-290, 2010. 